\title{
Training on synthetic ethylene-vinyl acetate bench model allows novice medical students to acquire suture skills ${ }^{1}$
}

\author{
Treinamento no modelo de bancada sintético de etileno vinil acetato permite que estudantes de \\ medicina iniciantes na prática cirúrgica adquiram habilidades de sutura
}

\begin{abstract}
Rafael Denadai', Rogério Saad-Hossne ${ }^{\mathrm{II}}$, Marie Oshiiwa ${ }^{\mathrm{III}}$, Érika Malheiros Bastos ${ }^{\mathrm{IV}}$
IGraduate student, Division of Plastic and Reconstructive Surgery, Department of Surgery, School of Medical Sciences, UNIMAR, Marilia-SP, Brazil. Main author. Conception, design, intellectual and scientific content of the study, involved in technical procedures, collection of study informations, interpretation of data, manuscript writing.

${ }^{I} \mathrm{PhD}$, Associate Professor, Division of Coloproctology, Department of Surgery, Botucatu Medical School, Sao Paulo State University (UNESP), Botucatu-SP, Brazil. Supervised all phases of the study, scientific and intellectual content of the study, manuscript writing and critical revision.

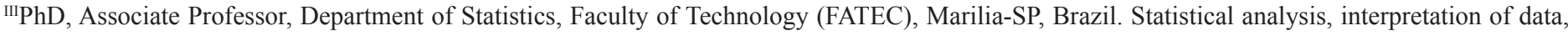
critical revision.

IvPhD, Associate Professor, Division of Plastic and Reconstructive Surgery, Department of Surgery, School of Medical Sciences, UNIMAR, MariliaSP, Brazil. Scientific and intellectual content of the study, interpretation of data and critical revision.
\end{abstract}

\begin{abstract}
PURPOSE: To assess the acquisition of suture skills by training on ethylene-vinyl acetate bench model in novice medical students.

METHODS: Sixteen medical students without previous surgery experience (novices) were randomly divided into two groups. During one hour group A trained sutures on ethylene-vinyl acetate (EVA) bench model with feedback of instructors, while group B (control) received a faculty-directed training based on books and instructional videos. All students underwent a both pre-and post-tests to perform two-and three-dimensional sutures on ox tongue. All recorded performances were evaluated by two blinded evaluators, using the Global Rating Scale.
\end{abstract}

RESULTS: Although both groups have had a better performance $(\mathrm{p}<0.05)$ in the post-test when compared with the pre-test, the analysis of post-test showed that group A (EVA) had a better performance $(\mathrm{p}<0.05)$ when compared with group B (control).

CONCLUSION: The ethylene vinyl acetate bench model allowed the novice students to acquire suture skills faster when compared to the traditional model of teaching.

Key words: Education, Medical. Surgery. Sutures. Teaching. Teaching Materials.

\section{RESUMO}

OBJETIVO: Avaliar a aquisição das habilidades de sutura com o treinamento no modelo de bancada de etileno vinil acetato em acadêmicos de medicina.

MÉTODOS: Dezesseis estudantes de medicina iniciantes na prática cirúrgica foram divididos aleatoriamente em dois grupos. Durante uma hora o grupo A treinou diferentes suturas no modelo de bancada de etileno vinil acetato (EVA) com feedback dos instrutores, enquanto os do grupo B (controle) receberam um treinamento dirigido por instrutor baseado em livros e vídeos didáticos. Todos foram submetidos à pré e pós-testes para realização de suturas bi e tridimensionais em língua de boi. As performances gravadas foram avaliadas por dois avaliadores cegos, utilizando a Global Rating Scale.

RESULTADOS: Embora os dois grupos tenham apresentado um melhor desempenho $(\mathrm{p}<0.05)$ no pós-teste quando comparado com o pré-teste, a análise do pós-teste mostrou que os alunos do grupo A (EVA) tiveram um melhor desempenho ( $p<0.05)$ quando comparados com os do grupo B (controle).

CONCLUSÃO: O modelo de etileno vinil acetato permitiu que os alunos adquirissem habilidades de sutura mais rapidamente quando comparado ao modelo tradicional de ensino.

Descritores: Educação Médica. Cirurgia. Suturas. Ensino. Materiais de Ensino. 


\section{Introduction}

Given that general practitioners are routinely faced with minor surgery interventions ${ }^{1-4}$ and that most physicians do not get satisfactory basic surgical skills during their academic formation ${ }^{5}$, it is necessary to establish a training program aimed at the teaching and improving of these technical skills to students in training ${ }^{1-5}$. In this context, as some practical activities with patients may infringe moral, ethical and legal aspects ${ }^{6}$, the training of technical skills outside the operating room based on simulation is becoming widely used in medical education ${ }^{6-8}$.

For this form of teaching and learning, many models and simulators have been described ${ }^{7,8}$. These models vary widely regarding their level of fidelity, as compared with the living human patient ${ }^{7,8}$. Although high-fidelity simulators are more attractive to trainees, there are some drawbacks that make them unsuitable for the teaching of basic skills ${ }^{8}$. Training on live or post-mortem animals and on fresh human cadavers (reality very close to the real) is currently discouraged because of infection risks, high costs, need for specialized facilities and legal and ethical aspects $^{6-8}$. In addition, the difficult access to high-fidelity virtual reality simulators and their high $\operatorname{costs}^{7,8}$ hinder their use, especially in developing countries ${ }^{9,10}$.

Alternatively, there are bench models ${ }^{7,8}$, that although considered as of low-fidelity, have advantages such as lower cost, portability, ability to be used in unsupervised practice and with the potential for repeated reuse of materials allowing students unlimited practice ${ }^{6-8}$. Recently, we proposed in this context the use of a synthetic ethylene-vinyl acetate (EVA) bench model to teach medical students the fundamental skills (suture techniques) required to assist with cutaneous surgical procedures and feel comfortable in the operating room ${ }^{11}$. In this previous report ${ }^{11}$, we include subjective observations about the acquisition of suture skills; however, in this scenario (simulated surgical training) the evaluation of performance and of this skills' gain should be objective $^{12}$ and preferably made by a previously validated test ${ }^{13,14}$.

Therefore, the purpose of this study was to evaluate the acquisition of suture skills with the training on EVA bench model in novice medical students, by means of a randomized, controlled and blinded study. A discussion with additional thoughts about how to use this synthetic model is also included.

\section{Methods}

\section{Study participants}

The protocol consisted of second-year medical students with no surgical skills background (novices) from the School of Medical Sciences at the University of Marilia, Sao Paulo, Brazil. All students with prior exposure to any surgical skills (use of surgical instruments, in suturing techniques or other procedures) were excluded. All subjects signed an informed consent form approved by the Ethics Committee for Human and Animal Research at the University of Marilia. The present study and all the procedures related to it are in accordance with the Declaration of Helsinki 1975, as amended in 1983.

\section{Didactic teaching session and pre testing}

Sixteen subjects were randomly selected from a group of 60 students who met the selection criteria outlined previously. On the day of the experiment, all students were taught how to use surgical instruments, as well as the techniques for the types of sutures required, by means of a video presentation which was repeated and commenced upon six times (verbal teaching based on video). This stage took one hour. Next, all participants underwent an individual pre-test, which consisted of making five simple interrupted sutures (two-dimensional) and five half-buried mattress sutures (three-dimensional) for the closure of two incisions $(8 \times 2$ $\mathrm{cm}$ each) on ox tongue. Each student was tested individually and had a total time of five minutes for each task.

\section{Training phase}

Immediately after the pre-test, all students were randomized into two groups of eight students each and began the tasks assigned to them. The two groups remained in separate rooms so they were unable to communicate with each other. In Group A, students practiced with surgical instruments and suturing by using the EVA bench model (Figure 1) with help of instructors (simultaneous feedback) according to the training described by our group ${ }^{11}$. In group B (control), the students received a faculty-directed training based on visualization of learning materials (textbooks and video-lesson) on the handling of surgical instruments and the manufacture of sutures. In order to standardize the learning, the instructors were instructed to teach the skills using the same method. This stage lasted one hour for both groups. 
Training on synthetic ethylene-vinyl acetate bench model allows novice medical students to acquire suture skills

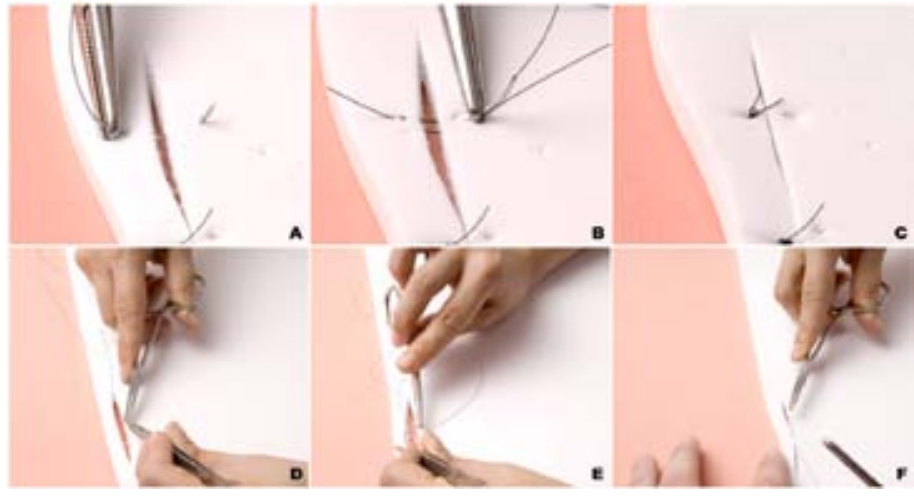

FIGURE 1 - Synthetic ethylene-vinyl acetate bench model simulating a (A-C) vertical mattress suture and a (D-F) subdermal interrupted suture.

\section{Post testing}

After the training, the instructors demonstrated to all students, for a period of the ten minutes, the making of simple interrupted sutures and half-buried mattress sutures. Immediately following this, the students were randomly assigned to a post-test (similar to pre-test). Each student was tested individually and had a total time of five minutes for each task.

\section{Task evaluation}

All pre-test and post-test maneuvers were recorded and saved. These digital videos were archived for later analysis and codified by using randomly assigned numbers by one of the investigators on the project. All of the recordings were independently evaluated in a blinded fashion by two surgical specialists who had no prior knowledge on the groups. The number of students who completed the proposed procedures (one or more stitches) and the number of stitches made were documented; the stitch was regarded as finalized only after the ends of the two surgical threads were cut. The Global Rating Scale (Table 1), previously validated ${ }^{13,14}$, was used to objectively evaluate the performance of each student in eight main areas. Each area was scored on a five-point scale; the lowest rating being one and the highest being five, making a maximum possible total score of 40 points.
TABLE 1 - Global Rating Scale ${ }^{13,14}$ used for the objective assessment of suture performances of students in the pre and posttests.

\begin{tabular}{|c|c|c|c|c|c|}
\hline \multicolumn{6}{|c|}{ Please rate the candidate's performance on the following scale: } \\
\hline $\begin{array}{l}\text { Respect for } \\
\text { tissue }\end{array}$ & 1 & 2 & 3 & 4 & 5 \\
\hline & $\begin{array}{l}\text { Frequently used } \\
\text { unnecessary } \\
\text { force on } \\
\text { tissues or } \\
\text { caused } \\
\text { damage by } \\
\text { inappropriate } \\
\text { instrument use }\end{array}$ & & $\begin{array}{l}\text { Careful handling } \\
\text { of tissue, but } \\
\text { occasional } \\
\text { inadvertent } \\
\text { damage }\end{array}$ & & $\begin{array}{l}\text { Consistently } \\
\text { handled tissues } \\
\text { appropriately } \\
\text { with minimal } \\
\text { damage }\end{array}$ \\
\hline \multirow[t]{2}{*}{ Time in motion } & 1 & 2 & 3 & 4 & 5 \\
\hline & $\begin{array}{c}\text { Many } \\
\text { unnecessary } \\
\text { moves }\end{array}$ & & $\begin{array}{l}\text { Efficient time } \\
\text { and motion, } \\
\text { but some } \\
\text { unnecessary } \\
\text { moves }\end{array}$ & & $\begin{array}{l}\text { Clear economy } \\
\text { of movement } \\
\text { and maximum } \\
\text { efficiency }\end{array}$ \\
\hline \multirow[t]{2}{*}{$\begin{array}{c}\text { Instrument } \\
\text { handling }\end{array}$} & 1 & 2 & 3 & 4 & 5 \\
\hline & $\begin{array}{l}\text { Repeatedly } \\
\text { makes } \\
\text { tentative or } \\
\text { awkward } \\
\text { moves with } \\
\text { instruments } \\
\end{array}$ & & $\begin{array}{l}\text { Competent use } \\
\text { of instruments, } \\
\text { but occasionally } \\
\text { awkward }\end{array}$ & & Fluid movements \\
\hline \multirow[t]{2}{*}{ Suture training } & 1 & 2 & 3 & 4 & 5 \\
\hline & $\begin{array}{l}\text { Awkward and } \\
\text { unsure with poor } \\
\text { knot tying, and } \\
\text { inability } \\
\text { to maintain } \\
\text { tension }\end{array}$ & & $\begin{array}{l}\text { Competent } \\
\text { suturing with } \\
\text { good knot } \\
\text { placement and } \\
\text { appropriate } \\
\text { tension } \\
\end{array}$ & & $\begin{array}{l}\text { Excellent suture } \\
\text { control with } \\
\text { correct suture } \\
\text { placement and } \\
\text { tension }\end{array}$ \\
\hline \multirow[t]{2}{*}{$\begin{array}{c}\text { Flow of } \\
\text { operation }\end{array}$} & 1 & 2 & 3 & 4 & 5 \\
\hline & $\begin{array}{l}\text { Frequently } \\
\text { stopped } \\
\text { operating, } \\
\text { seemed unsure } \\
\text { of next move }\end{array}$ & & $\begin{array}{l}\text { Demonstrated } \\
\text { some forward } \\
\text { planning and } \\
\text { reasonable } \\
\text { progression of } \\
\text { procedure }\end{array}$ & & $\begin{array}{l}\text { Obviously } \\
\text { planned } \\
\text { operation }\end{array}$ \\
\hline \multirow[t]{2}{*}{$\begin{array}{c}\text { Knowledge of } \\
\text { procedure }\end{array}$} & 1 & 2 & 3 & 4 & 5 \\
\hline & $\begin{array}{l}\text { Inefficient } \\
\text { knowledge of } \\
\text { procedure. } \\
\text { Looked unsure } \\
\text { and hesitant }\end{array}$ & & $\begin{array}{c}\text { Knew all } \\
\text { important steps } \\
\text { of procedure }\end{array}$ & & $\begin{array}{l}\text { Demonstrated } \\
\text { familiarity of } \\
\text { all steps of } \\
\text { procedure }\end{array}$ \\
\hline Final product & 1 & 2 & 3 & 4 & 5 \\
\hline
\end{tabular}

Final product

of unacceptable quality

Final product of

Final product of average quality superior quality

\begin{tabular}{cccccc}
\hline $\begin{array}{c}\text { Overall } \\
\text { performance }\end{array}$ & 1 & 2 & 3 & 4 & 5 \\
\hline & Very Poor & & Competent & Very Good \\
\hline Total score: & & & & $($ ) \\
\hline
\end{tabular}




\section{Statistical analysis}

The data was tabulated using the Microsoft Excel ${ }^{\circledR} 2000$ program. The individual measurements from Global Rating Scale were grouped into averages and standard deviations for each group. Bioestat ${ }^{\circledR}$ for Windows, version 5.0 was used to carry out statistical analyses. Student's T test was used for measurable variables, and Fisher's test for the analysis of categorical variables because of the small sample set. The level of significance was set at $5 \%$ for all analyzed variables.

\section{Results}

There was a difference in all evaluated parameters between the two groups, with Group A (trained on EVA model) showing better performance. The exception to this occurred in comparisons between groups that were performed in the pre-test.

\section{Student numbers and sutures done}

In the pre-test none of the 16 students managed to perform any of the two proposed procedures (no stitch) and therefore, there are no differences $(p>0.05)$ between the two groups (Group A versus Group B). In the post-test, a larger number of students in group A carried out a larger number of stitches in both types of evaluated sutures when compared with group B (control), as shown in Table 2.

TABLE 2 - Comparative analysis of number of students that performed stitches and of number of stitches done by each group in the post-test.

\begin{tabular}{cccccccc}
\hline Variable & \multicolumn{3}{c}{ Simple interrupted sutures } & \multicolumn{3}{c}{ Half-buried mattress sutures } \\
& Group A & Group B & p-value & Group A & Group B & p-value \\
\hline $\begin{array}{c}\text { Students who } \\
\text { have stitches (n=8) } \\
\text { Total number } \\
\text { of stitches (n=40) } \\
\begin{array}{c}\text { Number stitches } \\
\text { for student (M } \pm \text { SD) }\end{array}\end{array}$ & 7 & 3 & $0.0000^{*}$ & 7 & 1 & $0.0000^{*}$ \\
\hline
\end{tabular}

Group A = Ethylene-vinyl acetate bench model; Group B = Control; $\mathrm{M}=$ Mean; SD = Standard deviation; * Statistically significant.

Comparing the two evaluated periods (pre-test versus post-test), a larger number of students in both groups (A and B) carried out a larger number of stitches (both suture types) in the post-test period ( $\mathrm{p}=0.0000$ for all comparisons).

\section{Global rating scale}

In blinded evaluations of both pre-and post-tests, no inter-observer difference was detected between the examiners on the evaluation of means in Group A (EVA) for simple interrupted sutures or half-buried mattress sutures or in the analysis between means for group B (control) also for the two procedures ( $p>0.05$ for all comparisons).

Objective assessments conducted in the pre-test were considered minimal (means equal to 8 ) in all 32 performances; and, therefore, there are no differences between the two groups ( $p>0.05$ ). In the post-test, the average performances, evaluated using the Global Rating Scale in the performance of simple interrupted sutures, demonstrated that group A $(22.13 \pm 6.52)$ compared to group B (13.19 \pm 5.48$)$, presented a better performance $(\mathrm{p}=0.0001)$. This difference also occurred in the manufacture of half-buried mattress sutures, in which group A (20.63 \pm 7.68$)$ compared to group B (12.25 \pm 5.26$)$, also showed a better performance $(p=0.0006)$. Comparative analysis of mean examiner ratings based on the Global Rating Score is evidenced in the Figure 2.

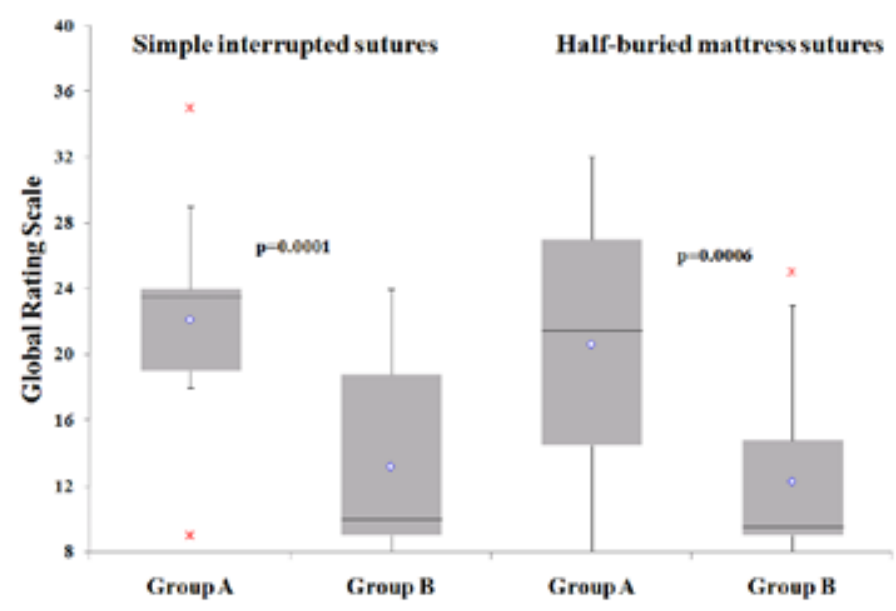

FIGURE 2 - Comparative analysis between all suture performances based on the Global Rating Scale of the both groups A (ethylene-vinyl acetate bench model) and B (control) for both types of stitches performed in the post-test. The heavy line is the median. The bars represent the range of the data. The symbols "*”" indicate the outliers.

When comparing the means of performance assessed by the Global Rating Scale between the two measurements taken (pre-test versus post-test), there was a better performance of both groups (A and B) in the manufacture of two types of sutures in the post-test ( $p=0.0000$ for all comparisons), as shown in Figure 3. 

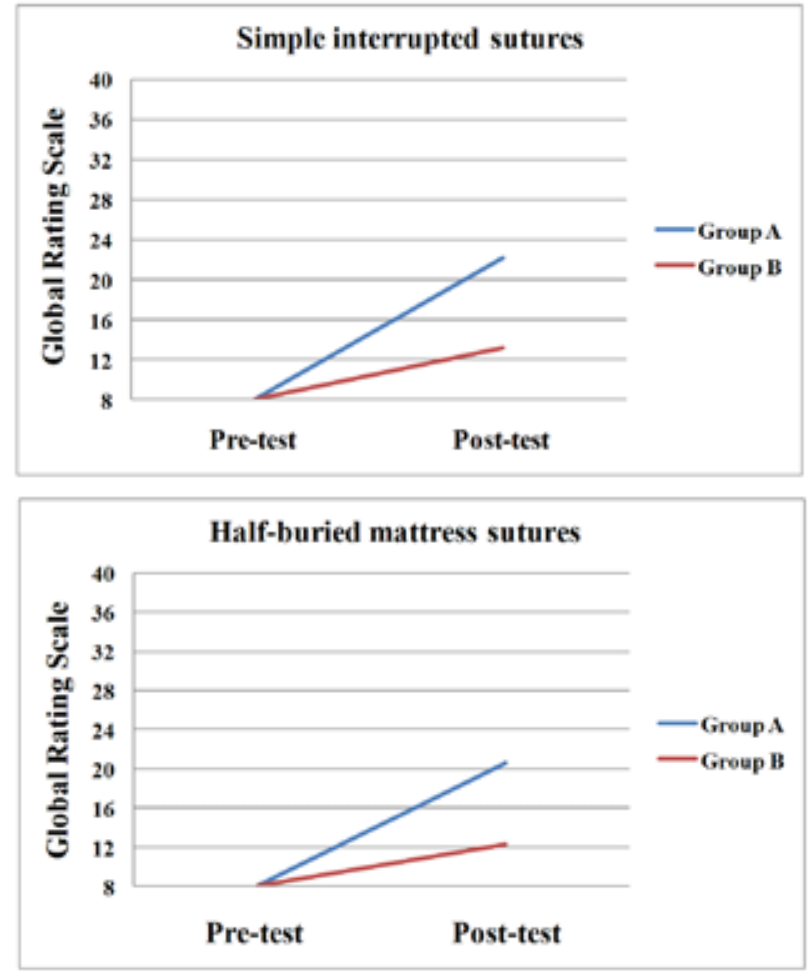

FIGURE 3 - Mean of the all (left) simple interrupted suture performances and (right) half-buried mattress suture performances pre-and post-tests based on Global Rating Scale. Both groups A (Ethylene-vinyl acetate bench model) and B (Control) showed better suture performances in the post-test when compared with the pre-test $(\mathrm{p}<0.05)$, but the group $\mathrm{A}$ improved their suture performances significantly more $(p<0.05)$ than did group B.

\section{Discussion}

Although the technique of suturing is the foundation upon which most surgical skills will be built ${ }^{15}$ (e.g., several cutaneous surgery procedures), such a foundation is not acquired by a large percentage of students during their training ${ }^{5,15}$. Many inanimate bench simulators have been described for their training ${ }^{10,16-18}$. Since 2008 we $^{11}$ use the synthetic EVA bench model for the teaching of sutures during medical undergraduation. Recently, other authors ${ }^{19}$ also described the same material (EVA) as an alternative to dermatology residents in the training of sutures. However, in these two reports ${ }^{11,19}$ the acquisition of skills was based only on subjective perceptions; therefore, it does not express the actual level of acquired skills ${ }^{20}$, specifically with this bench model.

In our ${ }^{11}$ previous study, besides presenting the EVA model, we also observed subjectively that the students who were trained at the bench model were able of performing minor surgical procedures under supervision of faculty expert. However, before the introduction of EVA, some students without the simulatorbased training also presented similar results. Thus, it was unclear whether it was exactly the training on the EVA model that made this possible; or if, in fact, only the instructions during classes and during the surgical procedure were the main determinants of this performance. Although it seems obvious that the gain of skills through training in any model is superior compared to the non-training, in proposing a new model ${ }^{11}$, this cannot be only in a subjectivity level ${ }^{20}$, because in the teaching of surgical skills, the measurement of gains should be carried out by an objective evaluation method ${ }^{12-14}$. Thus, the main focus of this study was to determine whether training on the EVA model, considered as of low-fidelity, can be used/recommended as a tool for teaching sutures during the medical undergraduation, through a comparative analysis with the faculty-directed learning based on didactic materials (video and text about suture training). Therefore, the aim of the study is not ascertain if the EVA is superior or inferior to other types of bench models.

In the present study, the option for the training during one hour and performing a pre-test after the students watched an instructional video were based on two reports ${ }^{15,26}$ on the teaching of sutures for medical students. The use of a control group that received no additional training was based on previous studies ${ }^{21-27}$ also on the acquisition of technical skills (training group versus notraining group, didactic training alone, no additional intervention, or learned independently from a prepared text). The adoption of faculty-directed learning was based on the study ${ }^{28}$ that showed that this form of teaching is superior to self-directed learning. The tools (videos and textbooks) of teaching used by the control group are recognized as a form of learning technical skills ${ }^{29,30}$. The number of instructors used (one instructor for every four students) was shown to be ideal for teaching suturing skills to medical students ${ }^{15}$. We selected two types of sutures ${ }^{31}$, because the possibility of training two and three-dimensional sutures seems to be one of the advantages of using the EVA bench model ${ }^{11,19}$.

All parameters (knowledge, decision making, communication, and dexterity), which constitute the concept of "surgical competence" can be measured; however, the measurement of technical ability and dexterity is the most problematic one ${ }^{32}$. Some authors ${ }^{33,34}$ carried out measurements of these technical skills after training on bench models; however, they did not use a previously validated test. The Global Rating Scale ${ }^{13,14}$ adopted as an evaluation tool in this study is part of the Objective Structured Assessment of Technical Skills ${ }^{14}$, which is considered nowadays as the gold standard for the objective evaluation of teaching surgical skills $^{12}$.

To the best of our knowledge, this is the first Brazilian study that evaluated objectively the teaching and learning of 
suturing skills in novice medical students, through training on lowfidelity bench model (EVA); there are similar Brazilian reports on the evaluation of other relevant issues in medical education ${ }^{35,36}$. The results of this study show that a larger number of students who practiced on the EVA model were able to make a larger number of stitches with greater dexterity. This was also found in previous studies ${ }^{23-25}$, which demonstrated that training in low-fidelity bench models is significantly better than the training in the control group (didactic training alone).

Students in the control group when confronted with the post-test, in most cases, failed to either begin making the stitches. Only three students were able to perform simple interrupted sutures, with a total of 5 stitches (ranging from 0 to 2 stitches per student) and only one of them held two half-buried mattress sutures. Since these few students had better performances in the post-test (compared to the pre-test), we can infer that this form of teaching (faculty-directed learning from didactic materials) can also determine (to a lesser degree) a gain of skills; this corroborates the previously described subjective feeling that before the introduction of EVA, some students could perform minor procedures under supervision of the faculty mentor.

There were a number of limitations in this report that must be acknowledged. First, there was no comparison of the EVA model with another bench model. This occurred because an extensive literature review (Scielo, Medline, and Embase databases) revealed no relevant reports in English that showed the superiority of one high-fidelity model over a low-fidelity one, or the superiority of a low-fidelity model over another low-fidelity one, for the teaching of suture skills for medical students. In fact, there is, so far, no standardization on an ideal model for teaching and learning of suture techiniques ${ }^{17}$. In addition, studies ${ }^{23-25}$ that compare different models (high fidelity versus low-fidelity) showed that there was a gain of surgical skills when both models were compared to training without simulation, but there are no differences between the models. In this context, the choice of a model to make comparisons with EVA model would be merely arbitrary and without scientific basis.

A second limitation was that the comparison used here (training on EVA versus faculty-directed learning based on educational materials) seems unnecessary at first, because it is described that there is more acquisition of technical skills when the training is based on simulation ${ }^{37}$. However, it is exactly this makes this comparison (training with simulator versus training without simulator) useful in the present study; if this comparative analysis were unfavorable to the use of EVA, the model might not be used/recommended as a tool of teaching, since it is known that simulated training is better ${ }^{37}$. Thus, by using a validated evaluation tool $^{13,14}$, the claim that by the training on EVA model students acquire suture skills, becomes objective and specific to EVA; this claim was previously based only on subjective perceptions ${ }^{11}$ and on studies that evaluated other low-fidelity simulators ${ }^{23-25}$. A third limitation is that these findings/results are limited to the skill of interest (suture techniques) and to the students' level of mastery of this skill.

Another limitation of this study is the fact that retention and transfer of skills to the clinical setting was not investigated. In this context, since it is shown that the retention of surgical skills is stronger when acquired in a manner interspersed with periods of rest, instead of teaching at a single time ${ }^{38}$, we encourage the use of the EVA model in different teaching sessions (classrooms and at home $)^{11}$, instead of training only in one hour. Because of some features of the EVA model, such as low cost, easy accessibility and handling, students can practice under supervision (immediate feedback) and practice at home, bringing the EVA with them to clarify doubts with the instructor (posterior feedback). In these moments, aspects such as spacing of stitches and eversion of the "wound edges" are evaluated and taught to the students again, having as a result a gain of skills over time. This form of teaching and learning (different teaching sessions spread over weeks with feedback from the instructor) has been described as the most effective method for teaching basic technical skills ${ }^{28}$. However, the time and the number of faculty surgeons available for this form of training is reduced ${ }^{28}$; the use of non-surgeon skills coaches ${ }^{39}$, trained students (students as teachers) ${ }^{40,41}$ or surgical residents ${ }^{42}$ as instructors can alleviate these limitations of the method.

The goal of surgical simulator-based training is to help trainees acquire and refine the technical skills ${ }^{8}$, for a subsequent contact with the real world (transfer of skills) ${ }^{6,23}$. In previous literature, there is evidence that the technical skills developed in bench models can result in performance improvements in cadavers, animal models and in the operating room ${ }^{6,23-25}$; and that for beginning students in surgical practice, the transfer of skills to the clinical environment is as good when obtained from cheap low-fidelity models as when it derives from expensive highfidelity models or virtual reality simulators?

Further studies are required to measure these aspects (transferability to clinical practice and retention of skills over time) using the EVA model. In addition, the acquisition of suture techniques with this model should be investigated for trainees in other levels of training (e.g., residents). 
Training on synthetic ethylene-vinyl acetate bench model allows novice medical students to acquire suture skills

\section{Conclusions}

Training on EVA bench model enables novice students to acquire suture skills better than the faculty-directed learning from didactic materials. This model can be used as a tool for teaching and learning of two and three-dimensional sutures during medical undergraduation, mainly for beginning students in surgical practice.

\section{References}

1. van Dijk CE, Verheij RA, Spreeuwenberg P, Groenewegen PP, de Bakker DH. Minor surgery in general practice and effects on referrals to hospital care: observational study. BMC Health Serv Res. 2011;11:2.

2. Brown JS, Smith RR, Cantor T, Chesover D, Yearsley R. General practitioners as providers of minor surgery - a success story? Br J Gen Pract. 1997;47(417):205-10.

3. Thompson AM, Park KG, Kelly DR, MacNamara I, Munro A. Training for minor surgery in general practice: is it adequate? J R Coll Surg Edinb. 1997;42(2):89-91.

4. Maguire N. Effect of a skills programme on minor surgical workload in general practice. Ir Med J. 2000;93(5):136-8

5. Forbes SS, Fitzgerald PG, Birch DW. Undergraduate surgical training: variations in program objectives and curriculum implementation across Canada. Can J Surg. 2006;49(1):46-50.

6. Anastakis DJ, Regehr G, Reznick RK, Cusimano M, Murnaghan J, Brown M, Hutchison C. Assessment of technical skills transfer from the bench training model to the human model. Am J Surg. 1999;177(2):167-70.

7. Reznick RK, MacRae H. Teaching surgical skills-changes in the wind. N Engl J Med. 2006;355(25):2664-9.

8. Hammoud MM, Nuthalapaty FS, Goepfert AR, Casey PM, Emmons S, Espey EL, Kaczmarczyk JM, Katz NT, Neutens JJ, Peskin EG; Association of Professors of Gynecology and Obstetrics Undergraduate Medical Education Committee. To the point: medical education review of the role of simulators in surgical training. Am J Obstet Gynecol. 2008;199(4):338-43.

9. Dorman K, Satterthwaite L, Howard A, Woodrow S, Derbew M, Reznick R, Dubrowski A. Addressing the severe shortage of health care providers in Ethiopia: bench model teaching of technical skills. Med Educ. 2009;43(7):621-7.

10. Taché S, Mbembati N, Marshall N, Tendick F, Mkony C, O'Sullivan P. Addressing gaps in surgical skills training by means of lowcost simulation at Muhimbili University in Tanzania. Hum Resour Health. 2009;7:64.

11. Bastos EM, Silva RD. Proposal of a synthetic ethylene-vinyl acetate bench model for surgical foundations learning. Suture training. Acta Cir Bras. 2011;26(2):149-52.

12. van Hove PD, Tuijthof GJ, Verdaasdonk EG, Stassen LP, Dankelman J. Objective assessment of technical surgical skills. Br J Surg. 2010;97(7):972-87.

13. Faulkner H, Regehr G, Martin J, Reznick R. Validation of an objective structured assessment of technical skill for surgical residents. Acad Med. 1996;71(12):1363-5.

14. Reznick R, Regehr G, MacRae H, Martin J, McCulloch W. Testing technical skill via an innovative "bench station" examination. Am J Surg. 1997;173(3):226-30.

15. Dubrowski A, MacRae H. Randomised, controlled study investigating the optimal instructor: student ratios for teaching suturing skills. Med Educ. 2006;40(1):59-63.
16. Ebram Neto J, de Paula PR, Celano RMG, Hirose K, Cauduro AB, Speranzini MB. Modelo de dispositivo para treinamento e avaliação das habilidades em técnica operatória. Acta Cir Bras. 1998;13(1):5860 .

17. MacFie CC, Colville RJ, Reid CA. Back to basics: a new suturing model. Br J Plast Surg. 2004;57(6):591-2.

18. Camelo-Nunes JM, Hiratsuka J, Yoshida MM, Beltrani-Filho CA, Oliveira LS, Nagae AC. Ox tongue: an alternative model for surgical training. Plast Reconstr Surg. 2005;116(1):352-4.

19. Gutiérrez-Mendoza D, Narro-Llorente R, Contreras-Barrera ME, Fonte-Ávalos V, Domíguez-Cherit J. Ethylene vinyl acetate (Foam): an inexpensive and useful tool for teaching suture techniques in dermatologic surgery. Dermatol Surg. 2011 May 26. doi: 10.1111/j.1524-4725.2011.02033.x. [Epub ahead of print]

20. Darzi A, Datta V, Mackay S. The challenge of objective assessment of surgical skill. Am J Surg. 2001;181(6):484-6.

21. Grierson L, Melnyk M, Jowlett N, Backstein D, Dubrowski A. Bench model surgical skill training improves novice ability to multitask: a randomized controlled study. Stud Health Technol Inform. 2011;163:192-8.

22. Rogers DA, Regehr G, MacDonald J. A role for error training in surgical technical skill instruction and evaluation. Am J Surg. 2002;183(3):242-5.

23. Grober ED, Hamstra SJ, Wanzel KR, Reznick RK, Matsumoto ED, Sidhu RS, Jarvi KA. The educational impact of bench model fidelity on the acquisition of technical skill: the use of clinically relevant outcome measures. Ann Surg. 2004;240(2):374-81.

24. Grober ED, Hamstra SJ, Wanzel KR, Reznick RK, Matsumoto ED, Sidhu RS, Jarvi KA. Laboratory based training in urological microsurgery with bench model simulators: a randomized controlled trial evaluating the durability of technical skill. J Urol. 2004;172(1):378-81.

25. Matsumoto ED, Hamstra SJ, Radomski SB, Cusimano MD. The effect of bench model fidelity on endourological skills: a randomized controlled study. J Urol. 2002;167(3):1243-7.

26. Xeroulis GJ, Park J, Moulton CA, Reznick RK, Leblanc V, Dubrowski A. Teaching suturing and knot-tying skills to medical students: a randomized controlled study comparing computer-based video instruction and (concurrent and summary) expert feedback. Surgery. 2007;141(4):442-9.

27. Wang CL, Schopp JG, Petscavage JM, Paladin AM, Richardson ML, Bush WH. Prospective randomized comparison of standard didactic lecture versus high-fidelity simulation for radiology resident contrast reaction management training. AJR Am J Roentgenol. 2011;196(6):1288-95.

28. Jensen AR, Wright AS, Levy AE, McIntyre LK, Foy HM, Pellegrini CA, Horvath KD, Anastakis DJ. Acquiring basic surgical skills: is a faculty mentor really needed? Am J Surg. 2009;197(1):82-8.

29. Dantas AK, Shinagawa A, Deboni MC. Assessment of preclinical learning on oral surgery using three instructional strategies. J Dent Educ. 2010;74(11):1230-6.

30. Yeung P Jr, Justice T, Pasic RP. Comparison of text versus video for teaching laparoscopic knot tying in the novice surgeon: a randomized, controlled trial. J Minim Invasive Gynecol. 2009;16(4):411-5.

31. Forsch RT. Essentials of skin laceration repair. Am Fam Physician. 2008;78(8):945-51.

32. Khan MS, Bann SD, Darzi AW, Butler PE. Assessing surgical skill using bench station models. Plast Reconstr Surg. 2007;120(3):793800.

33. Bjellerup M. Novel method for training skin flap surgery: polyurethane foam dressing used as a skin equivalent. Dermatol Surg. 2005;31(9 Pt 1):1107-11.

34. Altinyazar HC, Hosnuter M, Unalacak M, Koca R, Babucçu 
O. A training model for cutaneous surgery. Dermatol Surg. 2003;29(11):1122-4.

35. Silva CS, Souza MB, Silva Filho RS, Medeiros LM, Criado PR. E-learning program for medical students in dermatology. Clinics (Sao Paulo). 2011;66(4):619-22.

36. da Cruz JA, Sandy NS, Passerotti CC, Nguyen H, Antunes AA, Dos Reis ST, Dall'Oglio MF, Duarte RJ, Srougi M. Does training laparoscopic skills in a virtual reality simulator improve surgical performance? J Endourol. 2010;24(11):1845-9.

37. Lynagh M, Burton R, Sanson-Fisher R. A systematic review of medical skills laboratory training: where to from here? Med Educ. 2007;41(9):879-87.

38. Moulton CA, Dubrowski A, Macrae H, Graham B, Grober E, Reznick R. Teaching surgical skills: what kind of practice makes perfect?: a randomized, controlled trial. Ann Surg. 2006;244(3):4009.

39. Kim MJ, Boehler ML, Ketchum JK, Bueno R Jr, Williams RG, Dunnington GL. Skills coaches as part of the educational team: a randomized controlled trial of teaching of a basic surgical skill in the laboratory setting. Am J Surg. 2010;199(1):94-8.

40. Soriano RP, Blatt B, Coplit L, CichoskiKelly E, Kosowicz L, Newman L, Pasquale SJ, Pretorius R, Rosen JM, Saks NS, Greenberg L. Teaching medical students how to teach: a national survey of students-as-teachers programs in U.S. medical schools. Acad Med. 2010;85(11):1725-31.

41. Amorosa JM, Mellman LA, Graham MJ. Medical students as teachers: how preclinical teaching opportunities can create an early awareness of the role of physician as teacher. Med Teach. 2011;33(2):137-44.

42. Langenfeld SJ, Helmer SD, Cusick TE, Smith RS. Do strong resident teachers help medical students on objective examinations of knowledge? J Surg Educ. 2011;68(5):350-4

\section{Acknowledgment}

The authors express their gratitude to Tatiana Coppola for her support in the achievement of the photographs of the bench model.

\section{Correspondence:}

Rafael Denadai

Faculdade de Ciências Médicas

Universidade de Marília

Rua Paula Fabiana Tudela, 161

17516-707 Marília-SP Brasil

Tel./Fax: (55 14)3453-5456

silva.rdp@hotmail.com.br

Received: October 19, 2011

Review: December 21, 2011

Accepted: January 23, 2012

Conflict of interest: none

Financial source: none

${ }^{1}$ Research performed at Division of Plastic and Reconstructive Surgery, Department of Surgery, School of Medical Sciences, University of Marilia (UNIMAR), Marilia-SP, Brazil. 